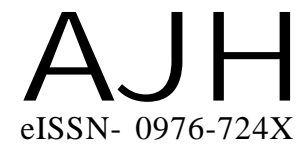

Received : 29.09.2016

Revised : 24.10.2016

Accepted : 09.11.2016
Members of the Research Forum

Associated Authors:

'Department of Horticulture,

Agricultural College and Research

Institute, Tamil Nadu Agriculutral

University, MADURAI (T.N.)
Author for correspondence V. KRISHNAMOORTHY Department of Horticulture, Agricultural College and Research Institute, Tamil Nadu Agriculutral University, MADURAI (T.N.) INDIA
THEASIAN JOURNAL OF HORTICULTURE

Volume 11 | Issue 2 | December, 2016 | 329-334

Visit us -www.researchjournal.co.in

RESEARCH PAPER

DOI : 10.15740/HAS/TAJH/11.2/329-334

\title{
Evaluation of cherry tomato [Solanum lycopersicum L. var. cerasiforme (Dunnal) A. Gray] genotypes for yield and quality traits
}

\section{R. RAMYA ${ }^{1}$, M. ANANTHAN ${ }^{1}$ AND V. KRISHNAMOORTHY}

ABSTRACT : The present research work was undertaken to identify the genetically divergent genotypes for higher yield and desirable quality traits under shade net in tropical climatic condition. The study consisted of eighteen genotypes collected from different places were raised, evaluated and studied for mean performance for yield and yield contributing traits and for quality traits. Based on per se performance of genotypes, the genotype Solan Red Round was adjusted as the best for tropical condition, since it had recorded superior performance for twelve characters viz., number of branches per plant (21.1), number of fruits per cluster (5.13), single fruit weight $(10.57 \mathrm{~g})$, pericarp thickness $(2.24 \mathrm{~mm})$, fruit yield per plant $(2.94 \mathrm{~kg})$, estimated fruit yield per hectare (73.42t), total chlorophyll content $(4.08 \mathrm{mg} / \mathrm{g})$, leaf area index (1.91), dry matter production $(2.5 \mathrm{t} / \mathrm{ha})$, titratable acidity $(0.42 \%)$, total soluble solids $\left(6.03^{\circ} \mathrm{Brix}\right)$ and lycopene $(1.96 \mathrm{mg} / 100 \mathrm{~g})$. It was followed by Kamanoor Local, K C Patti Local, Aadalur Local and Kodalangadu Local under shade net condition. The highest plant height $(5.18 \mathrm{~m})$ and number of clusters per plant (96.57) was recorded in Aranuttrumalai Local and Thandikudi Local, respectively.

KEY WORDS : Cherry tomato, Cerasifomae, Genotypes, Shadenet, Lycopene

HOW TO CITE THIS ARTICLE : Ramya, R., Ananthan, M. and Krishnamoorthy, V. (2016). Evaluation of cherry tomato [Solanum lycopersicum L. var.cerasiforme (Dunnal) A. Gray] genotypes for yield and quality traits. Asian J. Hort., 11(2) : 329-334, DOI : 10.15740/HAS/TAJH/11.2/329-334. 